\title{
Features of Ethno-Linguistic Identity Characteristic for Representatives of Different Ukrainian Linguistic Groups
}

\section{Особливості етнолінгвістичної ідентичності представників різних мовних груп України}

Eliso Hryshchuk

Ph.D. in Psychology, Assistant
Елісо Грищук

кандидат психологічних наук, асистент

E-mail: elisiliko@gmail.com

orcid.org/0000-0002-4890-0994

Alla Kovalenko

Dr. in Psychology, Professor,

Head of the Department

of Social Psychology
Алла Коваленко

доктор психологічних наук, професор, завідувач кафедри соціальної психології

E-mail: abk2015@ukr.net

orcid.org/0000-0001-6458-5325

Taras Shevchenko

National University of Kyiv,

Department of Social Psychology

$\square$ 64/13, Volodymyrska Str., Kyiv,

Ukraine, 01601
Київський національний університет

імені Тараса Шевченка, кафедра соиіальної психології $\triangle$ вул. Володимирська, 64/13, м. Київ, Україна

Original manuscript received August 31, 2018

Revised manuscript accepted March 28, 2019

\section{ABSTRACT}

The article analyzes features of ethno-linguistic identity characteristic for representatives of the main Ukrainian language groups: Ukrainian-speaking 
Ukrainians, Russian-speaking Ukrainians and Russian-speaking Russians. The main concepts of the ethno-linguistic identity theory and ethnic group vitality are examined; individual and collective strategies maintaining positive identity through language are described; the factors influencing language expressiveness in the structure of ethnic identity are presented. The article shows that Russian-speaking Ukrainians are more competent in both languages (Ukrainian and Russian); Ukrainian-speaking Ukrainians are highly proficient in their ethnic language and have predominantly an average level of Russian language proficiency; Russian-speaking Russians are characterized by good understanding and knowledge of their ethnic language only, at the same time they are low proficient in Ukrainian. As for Ukrainian-speaking Ukrainians and Russian-speaking Russians, their ethnic language competence coincides with their linguistic behaviour and attitudes. Russian-speaking Ukrainians do not show such coincidence; they are characterized by a discrepancy between the prevailing positive attitude to their ethnic language and their real linguistic behaviour. The data shows that the respondents do not choose mainly a language as a main ethnic-determining characteristic, however, in the system together with other distinctive features, it still occupies uppers rank positions for Ukrainian-speaking and Russian-speaking Ukrainians; family ties and psychological choices are more important for ethnic identification of Russian-speaking Russians. The vast majority of the respondents do not focus on their own ethnic status, paying more attention to personal, family and professional social characteristics. Ukrainian-speaking Ukrainians have the most steadfast ethnic identity, and marginal ethnic identity is predominantly observed among Russianspeaking Ukrainians. The relation between language and ethnic identity is described: correspondence between mother and ethnic language determines the respondents' positive ethnic identity, and vice-versa, their mismatch leads to appearance of ethnonihilistic tendencies.

Key words: ethno-linguistic identity, language, mother tongue, ethnic language, ethnic identity.

\section{Вступ}

Мова є однією з ознак етносу, тому динаміка етномовних процесів, як ніщо інше, віддзеркалює особливості етногенезу. Мова $є$ одним 3 найбільш значущих, а в деяких випадках i вирішальним виміром етнічної ідентичності, ㄲi використання впливає на формування та підтримку останньої. Навіть, у випадку переходу особистості або етнічної групи на іншу мову, етнічна ідентичність може залишатися досить стійкою, i, припинивши виконувати комунікативну функцію, мова залишатиметься символом етнічної ідентичності. 
В останні десятиліття дослідження взаємозв'язку мови та етнічної ідентичності проводяться на різних рівнях аналізу: психота соціолінгвістичному, етносоціологічному, етнографічному, соціально-психологічному тощо. Предметом вивчення в них виступають: мовні атитюди, мовленнєві маркери, соціолінгвістичні стереотипи тощо. На різних рівнях аналізу все більше уваги приділяється тому беззаперечному факту, що етнічна ідентичність пов'язана не стільки з реальним використанням мови всіма членами групи, скільки з іiі символічною роллю у формуванні почуття спорідненості 3 групою i одночасно в процесах міжгрупової диференціації. У поліетнічному суспільстві функціонують різні мови, і етнічна ідентичність кожної з діючих груп значною мірою обумовлена компетентністю іiі членів у «чужих» мовах та мірою збігу реального та бажаного їх використання (Данилюк, 2005; Донцов, Стефаненко \& Уталиева, 1997).

Аналіз особливостей етнолінгвістичної ідентичності представників основних мовних груп України, які безпосередньо або опосередковано можуть здійснювати вплив на процес їхньої міжособової взаємодії - стало метою нашої статті.

Основними завданнями стали: аналіз мовної поведінки, компетентності та ставлення до мови представників визначених мовних груп; виявлення взаємозв'язків цих показників із різними параметрами їхньої етнічної ідентичності; опис на основі аналізу цього взаємозв'язку особливостей етнолінгвістичної ідентичності досліджуваних груп.

\section{Методи та методики дослідження}

У ході дослідження використовувалися такі методи: теоретичні: аналіз наукової літератури 3 проблеми дослідження, узагальнення отриманої інформації; систематизація та інтерпретація отриманих даних; аналіз, порівняння й узагальнення теоретичного та емпіричного матеріалу; емпіричні: анкетування (вивчення мовної ідентичності, окремих параметрів етнічної ідентичності), психодіагностичне тестування (тест М. Куна i T. Макпартленда «Хто Я?»; методична розробка «Типи етнічної ідентичності» Г.У. Солдатової; методи описової та математичної статистики 
(аналіз та порівняння середніх значень, частотний, кореляційний (за критерієм Пірсона) аналізи).

Вибірка досліджуваних була поділена на три умовні групи, які відповідають найбільш представленим в Україні мовним спільнотам: україномовні українці (далі УУ), російськомовні українці (РУ) та російськомовні росіяни (РР). Поділ здійснювався на основі етнічного та мовного самовизначень респондентів. У результаті виокремлення цих груп вибірку досліджуваних можна представити наступним чином: 146 осіб увійшли до умовної групи УУ; 174 особи - групи РУ; 102 особи - групи РР. Загальна кількість респондентів 422 особи: 182 чоловіків і 240 жінок. Вік респондентів - від 20 до 45 років. Національність - українці та росіяни (за самовизначенням). Анкети представників інших національностей не враховувались та не оброблялись. Потрібно зауважити, що наведений розподіл не є репрезентативним для населення України як генеральної сукупності, а відтак наведені нижче дані несуть більше психологічний, ніж соціологічний зміст.

\section{Результати теоретичного дослідження}

У соціальній психології широко відомими є концепції, з позицій яких вивчається належність до тієї чи іншої етнічної спільноти: модель двох вимірів ідентичності Дж. Беррі (Berry, 1992) та теорія соціальної ідентичності Г. Таджфела і Дж. Тернера (Tajfel \& Turner, 1979). Модель, запропонована Дж. Беррі в руслі дослідження акультурації (Berry, 1992; Sam \& Berry, 2010), передбачає, що етнічні ідентичності зі своєю та чужою етнічними групами можуть існувати відносно незалежно один від одного. Водночас, Г. Таджфел i Дж. Тернер висувають загальний психологічний принцип, згідно з яким специфіка групової категоризації полягає у тому, що групова ідентифікація нерозривно пов'язана 3 іншим когнітивним процесом - диференціацісю (або оцінним порівнянням) категоризованих груп (Tajfel \& Turner, 1979).

Спираючись на теорію соціальної ідентичності, Г. Джайлз із співавторами досліджують роль мови у міжетнічних взаєминах та розробляють концепцію етнолінгвістичної життєздатності (Giles \& Johnson, 1981; Giles \& Rakić, 2014; Giles, Bourhis \& Taylor, 1977). 
Розглядаючи поняття етнолінгвістичної ідентичності, Г. Джайлз та його послідовники виходять 3 того, що при визначенні індивідами себе в якості членів етнічної групи міжгрупове порівняння може відбуватися на основі значущого для групи елемента культури мови, яка дозволяє досягти сприймання позитивної відмінності своєї групи від іншої (Giles, Bourhis \& Taylor, 1977).

Як вказує Г. Джайлз (Giles, Bourhis \& Taylor, 1977; Keblusek, Giles \& Maass, 2017), враховуючи те, що мова виступає важливою основою соціального порівняння та групової ідентичності, члени групи можуть використовувати різноманітні стратегії для досягнення «психолінгвістичної особливості», наприклад, акцентувати свій стиль мовлення, переходити на рідну мову тощо. 3 позицій теорії соціальної ідентичності Г. Джайлзом і П. Джонсон виокремлюються індивідуальні та колективні стратегії підтримки позитивної ідентичності за допомогою мови (Giles \& Johnson, 1987). Зокрема, при сприйманні міжгрупових меж як легкопроникних деякі члени групи (тієї, яка негативно оцінюється в суспільстві) можуть застосовувати стратегію індивідуальної мобільності, тобто відмовляються від мовних норм своєї групи та виявляють у такий спосіб прагнення перейти в домінантну групу. Подібний перехід може виражатися як у повній лінгвістичній та культурній асиміляції, так і в тому, що сфера використання етнічної мови поступово звужується, а кількість запозичень з другої мови зростає. Широке розповсюдження подібної стратегії може призвести до ситуації, коли мова збіднюється настільки, що обговорення 3 iï використанням будь-якої теми стає неможливим. В іншому випадку, подібна стратегія може призвести до втрати культурної специфіки тими індивідами, які цінують членство у своїй етнічній групі і розглядають мову як іï важливий вимір (Giles, Bourhis \& Taylor, 1977). У подібній ситуації може розвинутись субтрактивний білінгвізм, коли рідна мова підпорядкована нерідній, яка виступає домінантним мовленнєвим механізмом. Подібні тенденції активно вивчаються науковцями (Місержи, 2006; French, 2010; Karimzad \& Catedral, 2018; Levesque \& D. de Moissac, 2018), адже це характеризує мовну ситуацію багатьох країн, зокрема, й України. Проте, якщо міжгрупові межі сприймаються як непроникні, то члени етнолінгвістичних груп 3 негативною соціальною ідентичністю 
можуть застосовувати стратегії соціальної творчості, намагаючись реінтерпретувати різні елементи порівняння між групами (для порівняння обираються ще менш успішні групи, які, наприклад, взагалі не мають власної мови) (Giles \& Johnson, 1981).

Третій тип стратегій - соціальна конкуренція - зазвичай застосовується у випадку, коли не вдалося досягти позитивної етнічної ідентичності за допомогою індивідуальної мобільності або соціальної творчості. Прикладом дії подібної стратегії є багаточисленні ситуації, коли мова виявляється причиною громадських хвилювань.

Намагаючись виявити соціальні чинники, які впливають на вираженість мови в структурі етнічної ідентичності, Г. Джайлз iз співавторами розробили концепцію «етнолінгвістичної життєздатності», тобто здатності групи вижити як особливої спільноти, яка відіграє активну роль у міжгрупових взаєминах (Giles, Bourhis \& Taylor, 1977). У межах цієї концепцї аналізуються три види чинників, які впливають на збереження групою власної мови як життєздатного засобу комунікації: статус мови (економічний, політичний, історичний та лінгвістичний престиж), ii демографічні характеристики (абсолютна кількість користувачів, концентрація, частка серед членів інших груп), піi інституційна підтримка (представленість у 3MI, освіті, органах влади). Вимір сили або слабкості етнолінгвістичних груп у кожному з цих вимірів забезпечує їх умовний поділ на такі, які мають низьку, середню або високу життєздатність. Зокрема, існує ймовірність того, що членам груп 3 низькою етнолінгвістичною життєздатністю у поліетнічному оточенні загрожує мовна асиміляція або припинення існування як особливої спільноти.

На думку Г. Джайлза та П. Джонсон, на етнолінгвістичну ідентичність впливають ще такі два чинники, як сприйняті міжгрупові межі та множинна ідентичність (ідентичність 3 багатьма соціальними категоріями). Вони зробили припущення, що сприймання міжгрупових меж як міцних та непроникних приводить до зростання етнолінгвістичної ідентичності та проявів чіткої міжгрупової диференціації. У цьому випадку так само підкреслюється зв'язок між мовою та ідентичністю: члени етнічної групи можуть зміщувати лінгвістичні та нелінгвістичні 
межі 3 метою збереження міцності сприйнятих меж. Так, якщо група, яка має економічну необхідність взаємодіяти із сусідами, пом'якшує лінгвістичні межі, вона може одночасно укріплювати межі нелінгвістичні. I навпаки, якщо група відчуває послаблення нелінгвістичних меж (наприклад, збільшення кількості змішаних шлюбів), вона може спробувати протидіяти цьому, посиливши лінгвістичні межі (Giles \& Johnson, 1981).

Крім того, чим 3 меншою кількістю категорій людина може ідентифікуватися, тим стійкішою є ії етнолінгвістична ідентичність.

Значна увага у соціальній психології приділяється чинникам мови, які розглядаються в якості показників етнічної ідентичності представників груп, які взаємодіють між собою. Серед таких чинників виокремлюють використання мови, мовну компетентність, оцінку мови, надання їй переваги та вибір у комунікативній ситуації (Губогло, 1994).

Важливим для нашого дослідження $\epsilon$ те, що прихильники теорії етнолінгвістичної ідентичності вивчають також проблеми, пов'язані із використанням, оцінкою та зміною стилю мовлення у міжособовій взаємодії (Ehala, 2010; Keblusek, Giles \& Maass, 2017; Kymlicka \& Patten, 2003; Noels, 2014; Noels, Kil \& Fang, 2014).

\section{Результати емпіричного дослідження та дискусії}

Першим кроком нашого дослідження був кількісний аналіз даних, отриманих у ході анкетування, які характеризують мовну поведінку, компетентність та надання переваги респондентами своїй етнічній чи іншій мові. Після обробки отриманих результатів ми обчислили частоти та середні значення досліджуваних показників.

Результати частотного аналізу свідчать про те, що представники групи УУ значно частіше порівняно з РУ вказували українську мову в якості рідної $(97,3 \%$ та 52,0\% відповідно, $\mathbf{p} \leq 0,01)$, і навпаки, на відміну від україномовних українців (УУ), російськомовні українці (РУ) набагато частіше обирали російську мову в якості рідної (4,0\% та 33,9\% відповідно, $\mathrm{p} \leq 0,01)$.

Отримані показники зумовлені тим, що представники груп УУ та РР проживають у більш однорідному середовищі, а тому думають, розмовляють та пишуть переважно українською (у випадку УУ) або 
ж російською (у випадку РР). Саме в цих групах досліджуваних спостерігається найбільша міра збігу рідної та етнічної мови.

Відповіді групи РУ ілюструють ситуацію, коли внаслідок вищої етнолінгвістичної життєздатності російської мови в них відбулася мовна переорієнтація і домінуючою стала саме російська мова.

У зв’язку з цим, а також враховуючи специфіку досліджуваних регіонів та мовну ситуацію в країні загалом, нас цікавив також рівень компетентності досліджуваних в етнічній та «другій» мові. Аналіз відповідей на запитання анкети дозволив виокремити три рівні володіння тією чи іншою мовою. Перший рівень розуміння характеризується тим, що людина сприймає загальний зміст мовлення, але практично не володіє усною мовою, використовуючи лише стереотипи спілкування. Індивідам 3 другим рівнем розуміння мови доступне обговорення повсякденних тем та знайомство 3 пресою, проте часто вони вимушені підлаштовувати мовлення під наявні мовні та комунікативні можливості, інакше кажучи, можуть читати, проте пишуть та розмовляють 3 деякими труднощами. Третій рівень розуміння мови відповідає розумінню різних текстів, отриманню інформації з преси, здатності до самостійної побудови розгорнутого тексту, до діалогу практично на будь-яку тему. На даному рівні людина вільно читає та спілкується, іiі усне та письмове мовлення в основному правильне.

Отримані дані свідчать, що найвищі показники вільного володіння українською мовою виявлено у досліджуваних, які за етнічним самовизначенням належать до українців, незалежно від їхньої мовної ідентичності (УУ - 93,0\%; РУ - 86,0\%). Водночас, респонденти групи РР отримали приблизно однакові (низькі або середні) показники за кожним з трьох рівнів володіння українською мовою $(24,0 \%, 46,0 \%, 30,0 \%)$.

Вартими уваги $є$ показники третього рівня розуміння російської мови серед респондентів груп УУ та РУ. Так, незважаючи на те, що для досліджуваних УУ російська мова $є$ ні рідною, ні етнічною, проте вони виявили досить високий рівень мовленнєвої компетентності у ній - майже 51,0\%. Високим $\epsilon$ також рівень компетентності у російській мові серед досліджуваних групи РУ 95,0\%, і, звичайно ж, серед досліджуваних РP - 99,0\%.

Якщо взяти до уваги виокремлені Ж.Т. Уталієвою типи двомовності (Уталиева, 1995), то загалом за рівнем компетентності 
в обох мовах досліджувані розподілились наступним чином: групу УУ склали індивіди, в яких домінуючою $є$ українська мова, але компетентність у російській на рівні розуміння та побутового спілкування, що відповідає субординативному та рецептивному типу володіння двома мовами. До групи РУ, у свою чергу, увійшли особи з однаково високим рівнем соціального спілкування українською та російською мовами, що відповідає координативному типу двомовності. У респондентів, які увійшли до групи РР, домінантним виступає російська мова при компетентності в українській мові на рівні розуміння, що відповідає рецептивному типу володіння двома мовами.

Таким чином, найвищим рівнем компетентності у двох мовах володіють досліджувані групи РУ. Хоча, при досить високому рівні розуміння та володіння як українською, так і російською мовами серед російськомовних та україномовних українців, група російськомовних росіян характеризується високим рівнем розуміння та володіння лише своєю етнічною мовою при одночасному низькому рівні володіння українською мовою.

Це підтверджують і отримані нами дані за питаннями, які визначають мовну діяльність респондентів у різних сферах їхнього життя. Аналіз відповідей свідчить про панівне використання етнічної мови респондентами групи УУ практично у всіх сферах мовної діяльності, окрім сфери «спілкування 3 росіянами»: частота переходу на російську мову при спілкуванні $з$ росіянами практично не поступаєтсья використанню у цій сфері української мови - 63,0\% та 57,0\% відповідно. Досить високий показник використання російської мови - 53,0\%, порівняно з іншими сферами мовної діяльності, характеризує сферу «культура», що можна пояснити існуванням широкого спільного культурного простору 3 російським етносом.

Панівне переважання використання етнічної мови абсолютно у всіх сферах мовної діяльності спостерігається серед досліджуваних групи РР. Відносно частіше, порівняно 3 іншими сферами, досліджувані PР переходять на українську мову в ситуації спілкування з українцями (32,0\%).

У групі респондентів РУ переважання використання етнічної мови спостерігається лише у випадку спілкування з українцями $(85,0 \%) ;$ у сферах «сім'я», «робота» та «побут» різниця у частоті 
використання української та російської мов є незначною. Найбільш суттєве переважання російської мови серед досліджуваних РУ спостерігається в ситуації спілкування з росіянами $(98,0 \%)$ та у сфері «культура» - 90,0\%.

Звичайно, подібні результати пов'язані з домінантним статусом російської мови практично в усіх сферах життя у більшості досліджуваних нами регіонів. Тим не менше, можна говорити про те, що більш радикальними у плані використання етнічної мови виявились респонденти групи РР, в яких переважає у всіх сферах без винятку використання саме російської мови. Значно менш радикальними у цьому аспекті виявились респонденти групи УУ, a найбільш толерантними до використання тієї чи іншої мови виявились респонденти групи РУ.

Враховуючи припущення, що досить часто рівень ідентичності визначається не тільки реальним використанням мови, але й наданням їй переваги, ми включили до текста анкети питання, які б відображали ставлення респондентів до мови (зокрема: «Чи вважаєте Ви, що представники однієї національності повинні спілкуватися один з одним своєю рідною мовою?», «Чи вважаєте Ви, що діловодство та викладання у школах багатонаціональної держави повинні бути організовані на мові корінної більшості населення?»).

У результаті підрахунку відповідей досліджуваних на перше запитання виявилось, що представники групи УУ частіше погоджуються 3 даним твердженням (РУ - 38,5\%; РР - 47,8\% та УУ - 60,3\% відповідно, p $\leq 0,01)$. Водночас, у групах РУ та РP частіше заперечували це твердження, ніж в групі УУ $(42,5 \% ; 34,3 \%$ та $17,8 \%$ відповідно, $\mathrm{p} \leq 0,01)$. Якщо отримані у групі УУ результати $\epsilon$ цілком логічними (респонденти переважно погоджуються з думкою про те, що представники однієї національності повинні спілкуватися між собою рідною мовою), а результати групи РУ можна пояснити як форму своєрідного захисту (адже при переважному використанні ними в усіх сферах свого життя саме російської мови, етнічна (українська) мова все одно виконує певну символічну роль в їх єдності $з$ рідним етносом), то відповіді респондентів групи РР вимагають, на нашу думку, додаткового розгляду та вивчення.

При аналізі відповідей на друге запитання ми з'ясували, що представники групи УУ частіше погоджуються 3 цим твердженням (УУ - 78,0\%, РУ - 62,6\%, PР - 46,3\%, p $\leq 0,01$ ), а PР - заперечують 
(РР - 23,9\%, РУ - 19,5\%, УУ - 8,9\%, $\leq \leq 0,01)$. Отримані показники свідчать про цілком природний захист своїх етнічних інтересів представниками груп УУ та РР, при деякому маргінальному ставленні (хоча й з переважанням в бік своєї етнічності) представників групи РУ до власної етнічної мови в якості державної ознаки.

Важко не помітити, що у досліджуваних груп УУ та РP компетентність в етнічній мові збігається 3 мовною поведінкою та атитюдами i не співпадає у досліджуваних групи РУ. Для них характерна невідповідність між переважаючим позитивним ставленням до етнічної мови та реальною мовною поведінкою.

Розглядаючи мовну компетентність, мовну поведінку та надання переваги тій чи тій мові як чинники ідентифікації 3 власною етнічною групою, нас цікавило те, яке саме місце посідає для досліджуваних мова серед основних етноформуючих та етнодиференціюючих ознак (таблиця 1).

Таблиця 1. Розподіл етнодиференціюючих та етноформуючих ознак етносу в різних групах досліджуваних (у ранговому порядку - від найбільшої кількості виборів до найменшої)

\begin{tabular}{|c|c|c|c|c|c|c|c|c|c|c|c|}
\hline Уу & $\begin{array}{c}\text { Кіль- } \\
\text { кість } \\
\text { вибо- } \\
\text { рів }\end{array}$ & $\%$ & $\begin{array}{l}\text { Ран- } \\
\text { гове } \\
\text { місце }\end{array}$ & $\begin{array}{c}\text { PУ } \\
\text { Ознаки }\end{array}$ & $\begin{array}{c}\text { Кiль- } \\
\text { кість } \\
\text { вибо- } \\
\text { рів }\end{array}$ & $\%$ & $\begin{array}{l}\text { Ран- } \\
\text { гове } \\
\text { місце }\end{array}$ & $\begin{array}{c}P P \\
\text { Ознаки }\end{array}$ & $\begin{array}{c}\text { Кіль- } \\
\text { кість } \\
\text { вибо- } \\
\text { рів }\end{array}$ & $\%$ & $\begin{array}{l}\text { Ран- } \\
\text { гове } \\
\text { місце }\end{array}$ \\
\hline $\begin{array}{l}\text { Бажання } \\
\text { людини }\end{array}$ & 62 & 42 & 1 & Держава & 64 & 37 & 1 & $\begin{array}{l}\text { Національ- } \\
\text { ність батька }\end{array}$ & 42 & 64 & 1 \\
\hline Держава & 51 & 35 & 2 & $\begin{array}{l}\text { Бажання } \\
\text { людини }\end{array}$ & 55 & 32 & 2 & $\begin{array}{l}\text { Національ- } \\
\text { ність матері }\end{array}$ & 33 & 50 & 2 \\
\hline Мова & 50 & 34 & 3 & Мова & 53 & 31 & 3 & $\begin{array}{l}\text { Бажання } \\
\text { людини }\end{array}$ & 23 & 35 & 3 \\
\hline $\begin{array}{l}\text { Національ- } \\
\text { ність батька }\end{array}$ & 46 & 31 & 4 & $\begin{array}{l}\text { Звичаї, } \\
\text { традиції та } \\
\text { обряди }\end{array}$ & 42 & 24 & 4 & Мова & 21 & 32 & 4 \\
\hline $\begin{array}{l}\text { Національ- } \\
\text { ність матері }\end{array}$ & 42 & 28 & 5 & $\begin{array}{l}\text { Національ } \\
\text { ність батька }\end{array}$ & 39 & 23 & 5 & Держава & 14 & 21 & 5 \\
\hline $\begin{array}{l}\text { Звичаї, } \\
\text { традиції та } \\
\text { обряди }\end{array}$ & 41 & 28 & 6 & Зовнішність & 36 & 21 & 6 & $\begin{array}{l}\text { Звичаї, } \\
\text { традиції та } \\
\text { обряди }\end{array}$ & 12 & 18 & 6 \\
\hline $\begin{array}{l}\text { Місце } \\
\text { проживання }\end{array}$ & 25 & 17 & 7 & $\begin{array}{l}\text { Національ } \\
\text { ність матері }\end{array}$ & 33 & 19 & 7 & Зовнішність & 7 & 11 & $7-8$ \\
\hline Зовнішність & 18 & 12 & $8-9$ & $\begin{array}{l}\text { Місце } \\
\text { проживання }\end{array}$ & 28 & 16 & 8 & $\begin{array}{l}\text { Місце } \\
\text { проживання }\end{array}$ & 7 & 11 & $7-8$ \\
\hline $\begin{array}{l}\text { Риси } \\
\text { характеру, } \\
\text { психологія }\end{array}$ & 18 & 12 & $8-9$ & $\begin{array}{l}\text { Риси } \\
\text { характеру, } \\
\text { психологія }\end{array}$ & 24 & 14 & 9 & $\begin{array}{l}\text { Риси } \\
\text { характеру, } \\
\text { психологія }\end{array}$ & 2 & 3 & 9 \\
\hline
\end{tabular}


Аналіз отриманих показників виявив, що в усіх трьох групах значний відсоток досліджуваних взагалі не вказували мову в якості основної національної ознаки: серед респондентів групи УУ це спостерігалось у 63,0\%, РУ - 67,8\%, РР - у 68,7\% випадків. Ці дані є показовими, адже можуть свідчити про те, що, незважаючи на постійне зовнішньополітичне маніпулювання в нашій країні мовним питанням, на сьогоднішній день у свідомості громадян мова не $є$ головною ознакою для етнічного поділу на «своїх» та «чужих».

Цілком зрозумілими $€$ виявлені статистично значущі відмінності щодо ознаки «держава (громадянський вибір)», яка $\epsilon$ значно більш важливою для груп УУ та РУ порівняно з РР (35,0\%, $37,0 \%$ та $21,0 \%$ відповідно, $\mathrm{p} \leq 0,05)$, які, проживаючи на території іншої держави, відчувають деяку відокремленість від переважаючого тут етносу та відірваність від власної етнічно-національної групи. Крім цього, виявлено й інші статистично значущі відмінності, які свідчать про те, що УУ частіше за РУ звертають увагу на зовнішність при визначенні національності людини (12,0\% і 21,0\% відповідно, p $\leq 0,05)$, а УУ та РУ частіше, ніж РР виокремлюють «риси характеру» в якості етнодиференціюючої та етноформуюючої ознаки етносу $(12,0 \%, 14,0 \%$ та $3,0 \%$ відповідно, $\mathrm{p} \leq 0,05)$.

Водночас, у респондентів групи РР такі ознаки, як «держава» та «мова», зайняли рангові місця, ближчі до середніх, поступившись першими місцями таким ознакам, як «національність батька» та «національність матері». Порівняно із групами УУ та РУ вони обираються РР набагато частіше: «національність батька» - 31,0\%, $23,0 \%$ та 64,0\% відповідно ( $\leq 00,01)$; «національність матері» $28,0 \%, 19,0 \%$ та $50,0 \%$ відповідно $(\mathrm{p} \leq 0,01)$. Тобто, для РP, як представників нетитульного етносу країни, більш значущими та символічними ознаками єдності з власною групою $є$ саме родинні зв’язки, а не державний та громадянський вибір.

Після проведення статистичної обробки отриманих результатів (кореляційний аналіз на основі критерію Пірсона) у групі УУ виявлено позитивний кореляційний взаємозв'язок між фактом вказування респондентами даної групи української мови в якості рідної та переконанням, що діловодство в країні має вестися мовою корінної більшості населення (в даному випадку українською мовою) ( $<0,173 ; \mathrm{t}<0,005)$. Крім того, досліджувані, які погоджуються 3 твердженням про те, що представники однієї 
національності повинні спілкуватися між собою рідною мовою, також частіше погоджувались із питанням щодо офіційної мови держави $(\mathrm{p}<0,497 ; \mathrm{t}<0,001)$.

Таким чином, можна говорити про те, що в ситуації, коли рідна мова досліджуваного збігаєтсья з його етнічною та використовується практично в усіх сферах життя, це не лише визначає його ставлення до мови як до державотворчої ознаки, але й впливає на підвищення iï статусу в його очах.

Отримані кореляційні зв'язки у групі РУ дещо відрізняються від тих, які описані у групі УУ. Так, вибір досліджуваними групи РУ української мови в якості рідної значною мірою зумовлювався такими чинниками, як освіта та місце проживання: подібний вибір здійснювали переважно мешканці сіл або ж селищ міського типу 3 нижчим рівнем освіти ( $\mathrm{p}<-0,258 ; \mathrm{p}<-0,226 ; \mathrm{t}<0,001)$. Ще однією особливістю цієї групи є те, що жінки значно частіше, ніж чоловіки, надають значення мові як державотворчій ознаці та погоджуються 3 твердженням, що діловодство та викладання у багатонаціональній країні має вестися мовою корінної більшості населення ( $<<0,205$; $\mathrm{t}<0,001)$. Спільним із групою УУ $є$ те, що серед досліджуваних РУ так само виявлено позитивний кореляційний зв'язок між випадками згоди із тезою про необхідність представникам одного етносу спілкуватися рідною мовою та наданням мові корінної більшості населення держави статусу державної ( $<<0,210 ; \mathrm{t}<0,001)$. Проте, на відміну від УУ, дане твердження (про необхідність представникам одного етносу спілкуватися рідною мовою) підтримувалось частіше саме тими досліджуваними групи РУ, які вказували мову в якості суттєвої етноформуючої та етнодиференціюючої ознаки етносу $(\mathrm{p}<0,226 ; \mathrm{t}<0,001)$, що підтверджує факт значної символічної ролі мови для представників етнічної групи, навіть за умови, що вона не виконує для них власне комунікативну функцію.

Що ж стосується виявлених кореляційних взаємозв'язків у групі РР, то важливим $є$ наступний факт: ті 3 досліджуваних, які обирали мову в якості однієї з найважливіших ознак етносу, одночасно підтримували твердження про те, що представники однієї національності повинні спілкуватися між собою рідною мовою $(\mathrm{p}<0,330 ; \mathrm{t}<0,001)$. Враховуючи те, що подібний взаємозв'язок виявлено лише у даній групі досліджуваних, можна припустити, що для групи РР їхня рідна мова відіграє значно більше символічне 
значення, ніж для УУ та РУ, адже функціонуючи на території іншої країни, вона виступає однією з небагатьох ознак єдності 3 власним етносом. Крім того, виявилось, що подібна тенденція спостерігається переважно серед представників чоловічої статі $(\mathrm{p}<-0,318 ; \mathrm{t}<0,001)$.

Загалом, представлені нами дані частотного розподілу відповідей досліджуваних, результати аналізу середніх величин та проведеного кореляційного аналізу дають можливість виявити загальну характеристику особливостей використання рідної, етнічної та іншої мов та ставлення до неї серед груп УУ, РУ та PР. Проте, відповідно до завдань нашого дослідження, важливо з'ясувати характер взаємозв'язку одержаних даних 3 показниками етнічної ідентичності.

Зокрема, про місце етнічної ідентичності в структурі особистісної визначеності свідчать дані, отримані в ході аналізу показників за методикою М. Куна та Т. Макпартленда «Хто Я?»: переважна кількість досліджуваних в усіх трьох групах не схильні надміру акцентувати увагу на власній етнічній приналежності, надаючи більшого значення особистісним, сімейним і професійним характеристикам та соціальним ролям. Частіше акцентують увагу на своєму етнічному статусі УУ, в системі соціальних ідентичностей яких етнічна приналежність значно частіше займала високі місця порівняно $з$ респондентами груп РУ та РР (УУ - 31,0\%; РУ $15,0 \% ;$ PР $-12,0 \% ; \mathrm{p} \leq 0,05)$.

Результати за методикою «Хто Я?» демонструють особливості етнолінгвістичної ідентичності, а саме вплив мови на процес самокатегоризації досліджуваних. Етнічну приналежність на перших позиціях вказували частіше досліджувані групи УУ. Інакше кажучи, етнічна приналежність займає важливе місце в структурі соціальних ідентичностей досліджуваних, які володіють етнічною мовою. Поряд 3 цим, володіючи здебільшого середнім рівнем компетентності у домінантній та більш високостатусній у нашій країні російській мові, вони у такий спосіб (акцентуючи увагу на етнічній приналежності) намагаються захистити свою етнічність.

Виявлено позитивний кореляційний зв'язок між фактом вибору досліджуваними УУ української мови в якості рідної та стійкістю їхньої етнічної ідентичності ( $<<0,271 ; \mathrm{t}<0,005)$ (таблиця 2). Це свідчить про те, що збіг етнічної та рідної мови 
сприяє полегшенню процесу етноідентифікації та формуванню стійкої форми етнічної ідентичності.

Таблиця 2. Кореляційні зв'язки між показниками мовної та етнічної ідентичності в різних групах досліджуваних

\begin{tabular}{|c|c|c|c|c|c|c|}
\hline & \multicolumn{6}{|c|}{ Показники етнічної ідентичності } \\
\hline & \multicolumn{3}{|c|}{$\begin{array}{l}\text { Стійкість етнічної } \\
\text { ідентичності }\end{array}$} & \multicolumn{3}{|c|}{$\begin{array}{l}\text { Акцентуація етнічного } \\
\text { статусу }\end{array}$} \\
\hline & уу & Py & PP & уу & Py & PP \\
\hline Рідна мова (українська) & 0,271 & & & & & \\
\hline $\begin{array}{l}\text { Переконання, що представники однієї } \\
\text { національності повинні спілкуватися } \\
\text { між собою рідною мовою }\end{array}$ & & & & $-0,274$ & & \\
\hline $\begin{array}{l}\text { Переконання, що діловодство в країні } \\
\text { має вестися мовою корінної більшості } \\
\text { населення }\end{array}$ & & & & $-0,184$ & $-0,150$ & \\
\hline $\begin{array}{l}\text { Вибір респондентом мови як однієї } \\
3 \text { ознак національності }\end{array}$ & & 0,163 & & & & \\
\hline
\end{tabular}

Примітка: значення коефіцієнтів кореляції значущі на рівні $\mathrm{t}<0,001$ та $\mathrm{t}<0,005$.

Поряд із цим, чим частіше досліджувані групи Уу були переконані, що представники однієї національності повинні спілкуватися між собою рідною мовою, а діловодство в країні має вестися мовою корінної більшості населення, тим меншою мірою вони схильні акцентувати увагу на своїй етнічній приналежності $(\mathrm{p}<-0,274 ; \mathrm{t}<0,001 ; \mathrm{p}<-0,184 ; \mathrm{t}<0,005)$. Крім того, виявилось, що міра акцентуації етнічного статусу залежить від рівня освіти досліджуваних: більш освічені рідше акцентують увагу на власному етнічному статусі $(\mathrm{p}<-0,172 ; \mathrm{t}<0,005)$.

Високий рівень освіти досліджуваних РУ та їхнє ставлення до мови як державотворчої ознаки також знижують в них міру акцентуації власного етнічного статусу ( $<<-0,150 ; \mathrm{t}<0,005$ та $\mathrm{p}<-0,181 ; \mathrm{t}<0,005)$. Як видно 3 табл. 2, стійкість етнічної ідентичності досліджуваних РУ зв'язана не лише 3 визначенням мови важливою ознакою етносу $(\mathrm{p}<0,163 ; \mathrm{t}<0,005)$, але й високим рівнем освіченості $(\mathrm{p}<0,226 ; \mathrm{t}<0,001)$.

Щодо досліджуваних групи РР, то кореляційних взаємозв'язків між даними показниками виявлено не було. 
3 огляду на це, можна говорити, що індивіди, які характеризуються високою мірою усвідомлення своєї етнічності, загальним позитивним ставленням до неї, прийняттям себе як представника етнічної групи, меншою мірою проявляють поведінку «відстоювання» та протиставлення себе, своїх прав як окремого етнофора іншим етносам у процесі взаємодії.

Враховуючи вищезазначене, необхідним $\epsilon$ аналіз виявлених кореляційних зв'язків між різними типами етнічної ідентичності (дослідження особливостей етнічної ідентичності за допомогою методичної розробки Г.У. Солдатової «Типи етнічної ідентичності») та показниками мовної ідентичності.

Виявлено взаємозв'язки між «рідною мовою» та типами етнічної ідентичності: збіг у досліджуваних групи УУ рідної та етнічної мови зумовлює прояв у них позитивної етнічної ідентичності $(\mathrm{p}<0,175 ; \mathrm{t}<0,005) \mathrm{i}$, навпаки, їх розбіжність призводить до прояву етнонігілістичних тенденцій $\quad(\mathrm{p}<-0,224 ; \mathrm{t}<0,001)$. Аналогічна закономірність простежується й у тих досліджуваних групи УУ, які не визначають мову як одну з головних етнодиференціюючих та етноформуючих ознак етносу $(\mathrm{p}<-0,184 ; \mathrm{t}<0,005) .3$ огляду на це, логічно, що найчастіше етнонігілістичний тип етнічної ідентичності зустрічається серед досліджуваних, які характеризуються маргінальною етнічною ідентичністю або ж взагалі нездатністю віднести себе до жодної з етнічних груп $(\mathrm{p}<-0,174 ; \mathrm{t}<0,005)$.

Розглядаючи виявлені кореляції за гіперетнічними тенденціями у групі УУ, можна говорити про те, що існує позитивний взаємозв'язок між переконанням досліджуваних у тому, що представники однієї національності мають спілкуватися між собою рідною мовою і мірою прояву в них етноізоляційного типу етнічної ідентичності, тобто категоричність особи у цій позиції може зумовлювати виникнення переконання у перевазі свого народу над іншими, визнання необхідності «очищення» національної культури $\mathrm{i}$, навіть, ксенофобії $(\mathrm{p}<0,201 ; \mathrm{t}<0,005)$.

Виявлено також, що гіперетнічні форми прояву етнічної ідентичності, такі як етноегоїзм, етноізоляціонізм та національний фанатизм значно більшою мірою виявляється серед чоловіків групи УУ $(\mathrm{p}<-0,212 ; \mathrm{p}<-0,196 ; \mathrm{p}<-0,200 ; \mathrm{t}<0,005)$, а також в осіб, які проживають в містах (етноегоїзм $\mathrm{p}<0,263$; національний фанатизм $\mathrm{p}<0,263 ; \mathrm{t}<0,001)$. 
На відміну від україномовних українців, на прояв того чи іншого типу етнічної ідентичності у групі РУ зазначені вище мовні показники не мають жодного впливу, а визначається суто демографічними показниками: типи «етноіндиферентність» та «позитивна етнічна ідентичність» зустрічається переважно у досліджуваних вікового періоду середньої дорослості ( $<<0,209$; $\mathrm{p}<0,197 ; \mathrm{t}<0,001)$; «етноізоляціонізм» та «національний фанатизм» притаманні в основному досліджуваним чоловікам ( $<-0,165$; $\mathrm{p}<-0,189 ; \mathrm{t}<0,005)$ і разом 3 «етноегоїзмом» («етноізоляціонізм» та «національний фанатизм») виявляються переважно серед мешканців міст $(\mathrm{p}<0,191 ; \mathrm{p}<0,179 ; \mathrm{t}<0,005 ; \mathrm{p}<0,257 ; \mathrm{t}<0,005)$.

Схожа ситуація спостерігається і в результатах кореляційного аналізу даних у групі РР. Так, вищий рівень освіти досліджуваних цієї групи нівелює прояв такого типу етнічної ідентичності, як «етнонігілізм» ( $<<-0,305 ; \mathrm{t}<0,005)$. Як і в групі РУ, у досліджуваних РP вікового періоду середньої дорослості домінуючим типом етнічної ідентичності виступає «етноіндиферентність» ( $<0,241$; $\mathrm{t}<0,005)$, що свідчить про загальну для досліджуваних усіх груп тенденцію до зменшення ролі етнічної приналежності та іï важливості у повсякденному житті із переходом особистості на більш пізні вікові етапи (дорослості). Виявлено також протилежну закономірність, яка полягає у тому, що такий тип етнічної ідентичності, як «національний фанатизм», виявляється у РP більшою мірою в період ранньої дорослості, про що свідчить негативний кореляційний зв'язок ( $<<-0,309 ; \mathrm{t}<0,005)$, особливо серед представників чоловічої статі $(\mathrm{p}<-0,288 ; \mathrm{t}<0,005)$ та мешканців сільської місцевості ( $<<-0,249 ; \mathrm{t}<0,005)$.

\section{Висновки}

Підсумовуючи одержані результати, можна зробити висновок, що серед виокремлених етнолінгвістичних груп більшою мірою збіг рідної та етнічної мови спостерігається в групах РР та УУ. Водночас, більш компетентними в обох мовах (українській та російській) виявились представники групи РУ; представникам групи УУ притаманний високий рівень володіння своєю етнічною мовою та переважно середній рівень володіння російською мовою; 
група РР характеризується високим рівнем розуміння та володіння лише своєю етнічною мовою при одночасному низькому рівні володіння українською мовою. Більш радикальними у використанні своєї етнічної мови в різних сферах життєдіяльності виявились респонденти групи РР, значно менш радикальними у цьому плані виявились УУ, а найбільш толерантними у використанні тієї чи іншої мови виявились досліджувані групи РУ. Очевидно, що у респондентів груп УУ та РР компетентність в етнічній мові співпадає з мовною поведінкою та атитюдами i не співпадає у досліджуваних групи РУ. Для них характерна невідповідність між переважаючим позитивним ставленням до етнічної мови та реальною мовною поведінкою.

Незважаючи на те, що більшість досліджуваних усіх груп не обирали мову в якості основної етнодиференціюючої ознаки, в системі інших виокремлених ознак вона, все ж таки, займає в групі УУ та РУ перші рангові місця, водночас, для РР найбільш значущими ознаками єдності з власним етносом в'явились родинні зв'язки та психологічний вибір.

Переважна більшість досліджуваних не акцентує уваги на власному етнічному статусі, надаючи більшого значення особистісним, сімейним та професійним соціальним характеристикам. Це може свідчити про відносне благополуччя у сфері міжетнічної взаємодії, хоча (порівняно з іншими групами) в системі соціальних ідентичностей УУ їхня етнічна приналежність частіше займає високі місця. Найвища міра стійкості етнічної ідентичності також притаманна групі УУ, а маргінальна етнічна ідентичність переважно спостерігається серед досліджуваних групи РУ. Тобто, збіг етнічної та рідної мови сприяє полегшенню процесу етноідентифікації та формуванню стійкої форми етнічної ідентичності. Виявлено безпосередній взаємозв'язок між мовою та етнічною ідентичністю: збіг у досліджуваних рідної та етнічної мови зумовлює прояв у них позитивної етнічної ідентичності і навпаки, їх розбіжність призводить до прояву у них етнонігілістичних тенденцій.

Перспективу подальших досліджень ми вбачаємо у вивченні змін особливостей та параметрів етнолінгвістичної ідентичності описаних мовних груп під впливом нових соціальних чинників 
(військовий конфлікт, міграційні процеси в країні, зміна політичної влади тощо).

\section{Література}

Губогло М.Н. Интегрирующая функция языка. Социолингвистические проблемь развиваюшихся стран. Москва, 1994. С. 223-239.

Данилюк I. Мовні конфлікти та конструювання етнічної і національної ідентичності. Соиіальна психологія. 2005. Вип. 3. С. 43-51.

Донцов А.И., Стефаненко Т.Г., Уталиева Ж.Т. Язык как фактор этнической идентичности. Вопросы психологии. 1997. Вып. 4. С. 75-86.

Місержи С. Лінгвістична самоідентифікація та соціокультурна самоорганізація (на прикладі болгарської національної меншини в Україні). Наукові записки. Курасівські читання-2005. Сер. Політологія $i$ етнологія. 2006. Вип. 30. C. $298-308$.

Уталиева Ж.Т. Язык как фактор этнической идентичности: автореф. дисс. ... канд. психол. наук: 19.00.05. Москва, 1995. 19 с.

Berry, J.W., et al. (1992). Cross-cultural psychology: Research and applications. Cambridge, etc.: Cambr.Univ. Press.

Ehala, M. (2010). Ethnolinguistic vitality and intergroup processes. Multilingua, 29(2), 203-221. https://doi.org/10.1515/mult.2010.009

French, B.M. (2010). Maya Ethnolinguistic Identity. Published by: University of Arizona Press.

Giles, H., \& Johnson, P. (1981). The role of language in ethnic group relations. Intergroup Behaviour, J.C. Turner \& H. Giles (Eds.), (pp. 199-243). Oxford: Blackwell.

Giles, H., \& Rakić, T. (2014). Language attitudes: the social determinants and consequences of language variation. The Oxford handbook of language and social psychology Publisher: Oxford University Press, (pp. 3-26). Editors: Thomas M. Holtgraves.

Giles, H., \& Johnson, P. (1987). Ethnolinguistic identity theory: A social psychological approach to language maintenance. International Journal of the Sociology of Language, 68, 69-99. https://doi.org/10.1515/ijsl.1987.68.69

Giles, H., Bourhis, R.Y., \& Taylor, D.M. (1977). Towards a theory of language in ethnic group relations. Language, Ethnicity and Intergroup Relation, (pp. 307348). London: Academic Press.

Karimzad, F., \& Catedral, L. (2018). 'No, we don't mix languages': Ideological power and the chronotopic organization of ethnolinguistic identities. Language in Society, 47(1), 89-113. https://doi.org/10.1017/S0047404517000781

Keblusek, L., Giles, H., \& Maass, A. (2017). Communication and group life: How language and symbols shape intergroup relations. Group processes \& Intergroup relations, 20(5), 632-643. https://doi.org/10.1177/1368430217708864

Kymlicka, W., \& Patten, A. (2003). Language rights and political theory. Annual Review of Applied Linguistics, 23, 3-21. https://doi.org/10.1017/S0267190503000163

Levesque, A., \& de Moissac, D. (2018). Identité ethnolinguistique, continuité cultuelle et santé mentale chez les jeunes Franco-Manitobains: Une analyse exploratoire. Minorités linguistiques et société, 9, 185-206. https://doi.org/10.7202/1043502ar 
Noels, K.A. (2014). Language variation and ethnic identity: A social psychological perspective. Language \& Communication, 35, 88-96. https://doi.org/10.1016/j. langcom.2013.12.001

Noels, K.A., Kil, H., \& Fang, Y. (2014). Ethnolinguistic Orientation and Language Variation: Measuring and Archiving Ethnolinguistic Vitality, Attitudes, and Identity. Language and Linguistics Compass, 8(11), 618-628. https://doi. org/10.1111/lnc3.12105

Sam, D.L., \& Berry, J.W. (2010). Acculturation: when individuals and groups of different cultural backgrounds meet. Perspectives on Psychological Science, 5, 472-481. https://doi.org/10.1177/1745691610373075

Tajfel, H., \& Turner, J. (1979). An integrative theory of intergroup conflict. The social psychology of intergroup relations, W.S. Austin \& S. Worchel (Eds.). Montrey: Brooks/Cole.

\section{References}

Guboglo, M.N. (1994). Integrirujushhaja funkcija jazyka [The integrative function of language]. Sociolingvisticheskie problemy razvivajushhihsja stran - Sociolinguistic problems of developing counries, (pp. 223-239). Moscow [in Russian].

Danyliuk, I. (2005). Movni konflikty ta konstruiuvannia etnichnoi i natsionalnoi identychnosti [Language conflicts and the construction of ethnic and national identity]. Sotsialna psykholohiia - Social psychology, 3, 43-51 [in Ukrainian].

Doncov, A.I., Stefanenko, T.G., \& Utalieva, Zh.T. (1997). Jazyk kak faktor jetnicheskoj identichnosti [Language as a factor of ethic identity]. Voprosy psihologii Psychology issues, 4, 75-86 [in Russian].

Miserzhy, C. (2006). Linhvistychna samoidentyfikatsiia ta sotsiokulturna samoorhanizatsiia (na prykladi bolharskoi natsionalnoi menshyny $\mathrm{v}$ Ukraini) [Linguistic self-identification and socio-cultural self-organization (on the example of the Bulgarian national minority in Ukraine)]. Naukovi zapysky. Kurasivski chytannia-2005. Ser. Politolohiia i etnolohiia-Proceedings. Kurashiv readings-2005. Political science and ethnology, 30(1), 298-308 [in Ukrainian].

Utalieva, Zh.T. (1995). Jazyk kak faktor jetnicheskoj identichnosti [Language as a factor of ethic identity]. Extended abstract of candidate's thesis. Moscow [in Russian].

Berry, J.W., et al. (1992). Cross-cultural psychology: Research and applications. Cambridge, etc.: Cambr.Univ. Press.

Ehala, M. (2010). Ethnolinguistic vitality and intergroup processes. Multilingua, 29(2), 203-221. https://doi.org/10.1515/mult.2010.009

French, B.M. (2010). Maya Ethnolinguistic Identity. Published by: University of Arizona Press.

Giles, H., \& Johnson, P. (1981). The role of language in ethnic group relations. Intergroup Behaviour, J.C. Turner \& H. Giles (Eds.), (pp. 199-243).Oxford: Blackwell.

Giles, H., \& Rakić, T. (2014). Language attitudes: the social determinants and consequences of language variation. The Oxford handbook of language and social psychology Publisher: Oxford University Press, (pp. 3-26). Editors: Thomas M. Holtgraves. 
Giles, H., \& Johnson, P. (1987). Ethnolinguistic identity theory: A social psychological approach to language maintenance. International Journal of the Sociology of Language, 68, 69-99. https://doi.org/10.1515/ijsl.1987.68.69

Giles, H., Bourhis, R.Y., \& Taylor, D.M. (1977). Towards a theory of language in ethnic group relations. Language, Ethnicity and Intergroup Relation, (pp. $307-$ 348). London: Academic Press.

Karimzad, F., \& Catedral, L. (2018). 'No, we don't mix languages': Ideological power and the chronotopic organization of ethnolinguistic identities. Language in Society, 47(1), 89-113. https://doi.org/10.1017/S0047404517000781

Keblusek, L., Giles, H., \& Maass, A. (2017). Communication and group life: How language and symbols shape intergroup relations. Group processes \& Intergroup relations, 20(5), 632-643. https://doi.org/10.1177/1368430217708864

Kymlicka, W., \& Patten, A. (2003). Language rights and political theory. Annual Review of Applied Linguistics, 23, 3-21. https://doi.org/10.1017/S0267190503000163

Levesque, A., \& de Moissac, D. (2018). Identité ethnolinguistique, continuité cultuelle et santé mentale chez les jeunes Franco-Manitobains: Une analyse exploratoire. Minorités linguistiques et société, 9, 185-206. https://doi.org/10.7202/1043502ar

Noels, K.A. (2014). Language variation and ethnic identity: A social psychological perspective. Language \& Communication, 35, 88-96. https://doi.org/10.1016/j. langcom.2013.12.001

Noels, K.A., Kil, H., \& Fang, Y. (2014). Ethnolinguistic Orientation and Language Variation: Measuring and Archiving Ethnolinguistic Vitality, Attitudes, and Identity. Language and Linguistics Compass, 8(11), 618-628. https://doi. org/10.1111/lnc3.12105

Sam, D.L., \& Berry, J.W. (2010). Acculturation: when individuals and groups of different cultural backgrounds meet. Perspectives on Psychological Science, 5, 472-481. https://doi.org/10.1177/1745691610373075

Tajfel, H., \& Turner, J. (1979). An integrative theory of intergroup conflict. The social psychology of intergroup relations, W.S. Austin \& S. Worchel (Eds.). Montrey: Brooks/Cole.

\section{АНОТАЦІЯ}

Стаття присвячена аналізу особливостей етнолінгвістичної ідентичності представників основних мовних груп України: україномовних українців, російськомовних українців та російськомовних росіян. Розглядаються основні тези теорії етнолінгвістичної ідентичності та життєздатності етносу; описано індивідуальні та колективні стратегії підтримки позитивної ідентичності за допомогою мови; представлено чинники, що впливають на вираженість мови у структурі етнічної ідентичності. у статmі показано, що більш компетентними в обох мовах (українській та російській) виявились представники групи російськомовних українців; представникам групи україномовних українців притаманний високий рівень володіння своєю етнічною мовою та переважно середній рівень володіння російською мовою; група російськомовних росіян характеризується високим рівнем розуміння та володіння лише своєю етнічною мовою при одночасному низькому рівні 
володіння українською мовою. Серед україномовних українців та російськомовних росіян компетентність в етнічній мові збігається із мовною поведінкою та атитюдами і не збігається у російськомовних українців, для яких характерна невідповідність між переважаючим позитивним ставленням до етнічної мови та реальною мовною поведінкою. Наведено дані, які засвідчили, що більшість досліджуваних не обирають мову в якості основної етнодиференціюючої ознаки, проте, в системі інших виокремлених ознак вона, все ж таки, займає в групі україномовних та російськомовних українців перші рангові місця; для російськомовних росіян більш значущими ознаками $є$ родинні зв'язки та психологічний вибір. Переважна більшість досліджуваних не акцентує уваги на власному етнічному статусі, надаючи більшого значення особистісним, сімейним та професійним соціальним характеристикам. Найвища міра стійкості етнічної ідентичності притаманна україномовним українцям, а маргінальна етнічна ідентичність переважно спостерігається серед російськомовних українців. Описано взаємозв'язок між мовою та етнічною ідентичністю: збіг рідної та етнічної мови зумовлює прояв у досліджуваних позитивної етнічної ідентичності і, навпаки, їх розбіжність призводить до вияву в них етнонігілістичних тенденцій.

Ключові слова: етнолінгвістична ідентичність, мова, рідна мова, етнічна мова, етнічна ідентичність.

\section{Грищук Элисо, Коваленко Алла. Особенности этнолингвистичской идентичности представителей разных языковых групп Украины}

\section{АННОТАЦИЯ}

Статья посвящена анализу особенностей этнолингвистической идентичности представителей основных языковых групп Украины: украиноязычных украинцев, русскоязычных украинцев и русскоязычных россиян. Рассматриваются основные положения теории этнолингвистической идентичности и жизнеспособности этноса; описано индивидуальные и коллективные стратегии поддержки позитивной идентичности с помощью языка; представлены фракторы, влияющие на выраженность языка в структуре этнической идентичности. В статье показано, что более компетентными в обоих языках (украинском и русском) оказались представители группы русскоязычных украинцев; среди представителей группы украиноязычных украинцев преобладает высокий уровень владения своим этническим языком и преимущественно средний уровень владения русским языком; группа русскоязычных россиян характеризуется высоким уровнем понимания и владения только своим этническим языком при одновременном низком уровне владения украинским языком. Среди украиноязычных украинцев и русскоязычных россиян компетентность в этническом языке совпадает с языковым поведением и аттитюдами и не совпадает у русскоязычных украинцев, для которых характерно несоответствие между преобладающим положительным 
отношением к этническому языку и реальным языковым поведением. Показано, что большинство исследуемых не выбирают язык в качестве основного этнодифференцирующего признака, однако, в системе других выделенных признаков он, все же, занимает в группе украиноязычных и русскоязычных украинцев первые ранговые места; для русскоязычных россиян более значимыми признаками являются родственные связи и психологический выбор. Подавляющее большинство исследуемых не акцентирует внимания на собственном этническом статусе, предоставляя большее значение личностным, семейным и профессиональным социальным характеристикам. Высшая мера устойчивости этнической идентичности присуща украиноязычным украинцам, а маргинальная этническая идентичность преимущественно наблюдается среди русскоязычных украинцев. Описана взаимосвязь между языком и этнической идентичностью: совпадение родного и этнического языка обусловливает проявление у исследуемых положительной этнической идентичности $u$, наоборот, их расхождение приводит $k$ проявлению у них этнонигилистических тенденций.

Ключевые слова: этнолингвистическая идентичность, язык, родной язык, этнический язык, этническая идентичность. 